ALICJA KOSIM

University of Warsaw, Poland

e-mail: alicjakosim@student.uw.edu.pl

\title{
Multilingual Shakespeare in the Polish Translation of The Merry Wives of Windsor by John of Dycalp (Placyd Jankowski) ${ }^{1}$
}

\begin{abstract}
Puste kobiety z Windsoru (1842) is the first complete Polish translation of The Merry Wives of Windsor and the first translation by Placyd Jankowski (1810-1872), one of the most extraordinary Shakespeare translators into Polish, who published under the pseudonym of John of Dycalp. His work proves to be an interesting case study on two grounds. First, it is an example of the complexities of translating verbal humor, and secondly, an interesting case of literary rewriting which takes into account the specificity of the target audience to the effect of, as it were, relocating the play from the English countryside to the Polish Kresy (Borderlands). Consequently, it is possible to examine Dycalp's translation as a linguistic experiment, especially with regards to the parts of Sir Hugh Evans, the Welsh parson, and of Doctor Caius, the French physician. Furthermore, Dycalp's translation serves as an example of domestication directed at a very specific audience, which adds an unexpected dimension to the issue of multilingualism in Shakespeare's work as well as to the concept of stage as a broadly understood cultural space.
\end{abstract}

Keywords: The Merry Wives of Windsor, Puste kobiety z Windsoru, John of Dycalp, Placyd Jankowski, William Shakespeare, drama translation

The issue of multilingualism in William Shakespeare's plays has attracted much scholarly attention. "Cross-language situations", the very notion of translation, and the representation of what might be considered foreign or exotic, all of which might be found in Shakespeare's plays, prove that the playwright was well aware of the dramatic potential of juxtaposing languages and cultures. ${ }^{2}$ Moreover,

1 The article is based on the research material collected within the framework of the state-funded project The e-Repository of the Polish $19^{\text {th }}$-century Shakespeare Translations: Resources, Strategies and Reception (NCN Opus 9, UMO-2015/17/B/HS2/01784, 2016-2018).

2 D. Delabastita, "If I know the letters and the language»: translation as a dramatic device in Shakespeare's plays, in: T. Hoenselaars (ed.), Shakespeare and the Language of Translation, London 
the relation between the standard English language and all its varieties as well as the position these varieties held in English culture were among the most significant concerns of early modern English drama. ${ }^{3}$ Consequently, the multilingual aspect of Shakespeare in translation might broaden the perspective and open yet another vista of research.

The translation I intend to discuss here, Puste kobiety z Windsoru by Placyd Jankowski, is a very peculiar example of the pioneering effort to negotiate equivalence in a radically different cultural environment. On the one hand, it is the first Polish rendering of The Merry Wives of Windsor, considered to be one of the most English (i.e. representing the specifically English provincial culture of the time) comedies by Shakespeare; on the other hand, it is a largely forgotten text or, to be more precise, a text never appropriately acknowledged by the target audience. Furthermore, it is a forgotten translation by a very much forgotten translator, ignored by the theatre and originating in a cultural context that no longer exists, thus, a translation lacking a real point of reference. Puste kobiety $z$ Windsoru transfers Shakespeare's play into the reality of the region of Kresy (the Borderlands), the former Eastern part of the Polish Commonwealth (now the territory of Lithuania and Belarus), and therefore into a space that is perceived as an enigma:

The revolving globe of the earth has become very small, and, geographically speaking, there are no longer any uncolored areas on it. In Western Europe, however, it is enough to have come from the largely untraveled territories in the East or North to be regarded as a visitor from Septentrion, about which only one thing is known: it is cold. ${ }^{4}$

The Borderlands, as described by Czesław Miłosz in his autobiography Native Realm, remain a mysterious and elusive place, even for most of the contemporary Polish audiences. Hence, the case of John of Dycalp's translation appears valuable not only as one of the earliest examples of the Polish reception of Shakespeare, but also as a literary artefact that reflects a reality that no longer exists, not because of the natural passage of time, but owing to the radical political, ethnic, and cultural reshaping of the region for which it was produced.

Placyd Jankowski was an extraordinary and controversial figure of the Polish literary world. Once a member and a clergyman of the Uniate Church (Eastern Catholic Church), which was closely connected to the structures of the Roman Catholic Church, he later converted to the Orthodox Church. ${ }^{5}$ His apparently tur-

2012, p. 31; P. Blank, Dialects in the plays of Shakespeare, in: B.R. Smith (ed.), The Cambridge Guide to the Worlds of Shakespeare. Volume 2. The World's Shakespeare, 1660-Present, New York 2016, p. 219.

3 D. Delabastita, T. Hoenselaars, "If but as well I other accents borrow, that can my speech diffuse». Multilingual perspectives on English Renaissance drama, in: idem (eds.), Multilingualism in the Drama of Shakespeare and His Contemporaries, Amsterdam-Philadelphia 2015, pp. 1, 7.

${ }^{4}$ Cz. Miłosz, Native Realm: A Search for Self-definition, C.S. Leach (transl.), Berkeley 1981, p. 2.

5 The policy of russification sought to separate the Uniates from the Roman Catholic Church and to incorporate the Uniate Church into the Orthodox Church, thus assimilating the Uniates with the Eastern culture. After the official liquidation of the Union of Brest in 1839, Placyd Jankowski was among those Uniate clergymen who chose to convert to the Orthodox Church. In the Polish context, his decision could have been regarded as unpatriotic and might have heavily influenced the reception of his works. 
bulent spiritual life was complemented by a stunning literary career as a prolific writer and translator. The sheer volume and astonishing generic variety of his literary output, which included novels, short stories, memoirs, poetry, and press articles, reflected his wide interests and exceptional gift for storytelling. His idiosyncratic writing style, often compared to that of Charles Dickens or Laurence Sterne, was strengthened by humouristic devices and bold experiments in terms of form and content, as in the case of Powieść składana [A duet novel] (1843), a novel written in collaboration with an eminent Polish writer and literary critic, Józef Ignacy Kraszewski. ${ }^{6}$

It seems that Jankowski's literary activity reflected his environment and the specificity of the place where he lived: the Borderlands (Kresy) were a mixture of different nationalities, cultures, religions, and languages. Against that diversified background, Jankowski emerges as a real polyglot who, due to his education, knew not only classical languages (Latin, Hebrew, Greek), but also Western European languages (English, German, French, Italian), as well as Slavic languages (Russian, Czech, Belarussian). ${ }^{7}$

Most of Jankowski's works were published under the foreign-sounding pen name "John of Dycalp", based on his surname and his name read backwards. It was also under this pseudonym that he published his translations of Shakespeare's plays. Significantly, John of Dycalp was befriended by and closely cooperated with Ignacy Hołowiński, the very first Polish translator of Shakespeare. Eventually, they both contributed to the enterprise that supposedly aimed at translating the whole Shakespearean canon into Polish ${ }^{8}$ Dycalp published four translations, two comedies - Puste kobiety z Windsoru (The Merry Wives of Windsor, 1842) and Pótnocna godzina (Twelfth Night, 1845) - and both parts of Henryk IV (Henry $I V, 1847){ }^{9}$

The aim of this paper is to analyse Dycalp's first translation, Puste kobiety $z$ Windsoru, published in Vilnius, in 1842. Interestingly enough, while it is the

6 W. Tarnawski, O polskich przekladach dramatów Szekspira, Kraków 1914, p. 57. Jankowski’s most prominent works include: Chaos (1835), Pisma przedślubne i przedsplinowe (1841), Zaścianek (1841), Przeczucie - komedia w 3 aktach (1842), Pamiętnik Elfa (1843), Opowiadania (1843), Doktor Panteusz w przemianach (1845), Sędzia Pieniażek (1845), Nowe opowiadania (1847), Kilka wspomnień uniwersyteckich (1849), Fanaberie pana Starosty Kaniowskiego (1873), Z pism pośmiertnych (1873).

7 W. Charkiewicz, Placyd Jankowski (John of Dycalp). Życie i twórczość, Wilno 1928, p. 157.

8 Ibid., p. 161; A. Cetera, Smak morwy. U źródel recepcji przektadów Szekspira w Polsce, Warszawa 2009, p. 38.

9 Ignacy Hołowiński published two volumes of his translations in Vilnius in 1839 and 1841 respectively. They included Hamlet, Romeo and Juliet, A Midsummer Night's Dream, Macbeth, King Lear and The Tempest. Dycalp's translation of Henry IV was published in 1847 as the third volume of the series. These editions, along with the earlier Shakespeare translations by Dycalp and those of Romeo and Juliet by Julian Korsak (1840) and King John by Józef Korzeniowski (1844), all published in Vilnius, served to confirm the pioneering role that the city played as a cultural centre for the first theatrical and translation endeavours concerning Shakespeare in the Polish context (J. Komorowski, Shakespeare w Wilnie 1786-1864, "Pamiętnik Teatralny" 1986, no. 2-3, pp. 181-200; idem, Polskie szekspiriana. 2. Shakespeare księdza Kefalińskiego, "Pamiętnik Teatralny" 1991, no. 1, pp. 11-17; idem, Shakespeare and the Birth of Polish Romanticism: Vilna 1786-1846, "Theatre Research International" 1996, no. 2, pp. 141-146). 
first complete translation of The Merry Wives of Windsor into Polish, it has been also referred to as "half-translation, half-adaptation/remake". ${ }^{10}$ My analysis focuses on two aspects of Dycalp's translation that stay in connection with this hybrid characterization. First, Dycalp's work might be analyzed as an example of the daring attempt at translating verbal humor in the initial phase of Shakespeare's reception, and secondly, as an interesting case of a literary rewriting, which takes into account the specificity of the target audience to the effect of relocating the play from the English countryside to the Polish Kresy (Borderlands), and thus domesticating Shakespeare's comedy.

The very fact that Dycalp chose to translate The Merry Wives of Windsor, and not any other play, as his first attempt at rendering Shakespeare into Polish, is meaningful. The status this comedy held in the Polish theatrical tradition of the $18^{\text {th }}$ and $19^{\text {th }}$ centuries differs from its contemporary reception in Poland. The Merry Wives of Windsor, or rather its far-fetched adaptation or transposition, was one of the first traces of Shakespearian plots that can be found in the early Polish theatrical reception. In 1782, Franciszek Zabłocki authored a play entitled Samochwat, albo Amant Wilkołak ['A Bragger, or a Werewolf Lover'], an adaptation of Shakespeare's comedy produced in 1777 by a French dramatist, Jean-Marie Collot d'Herbois, who in turn based his work on the French translation of The Merry Wives of Windsor by Letourner ${ }^{11}$. Although Zabłocki chose to domesticate the setting and follow the convention of the $17^{\text {th }}$-century French comedy, the main conflict and the dramatic functions of most of the characters remain close to Shakespeare's original work ${ }^{12}$. That earlier presence of this dramatic plot in the Polish theatrical tradition may have contributed to Dycalp's choice. Moreover, The Merry Wives of Windsor appears to be closely linked to Dycalp's own literary interests, as it bears a resemblance to the genre of the farce, or krotochwila, which in the Polish literary tradition refers to a theatrical piece featuring witty exchanges, comic intrigues and rather trivial conflicts. ${ }^{13}$ Last but not least, Shakespeare's comedy strongly depends on its provincial middle-class English context, which was easily transferable and adaptable to the reality of the Polish Borderlands.

The Merry Wives of Windsor is very much focused on the notion of Englishness, English identity, and English language. ${ }^{14}$ These issues are closely linked to the multilingual, or multicultural, aspects of the comedy, and they also remain the main source of its linguistic humour. The characters of Sir Hugh Evans, a Welsh parson, and Doctor Caius, a French physician, are both vehicles and targets of the verbal humour in the play:

10 W. Tarnawski, op. cit., p. 57.

11 A. Żurowski, Szekspiriady polskie, Warszawa 1976, p. 192.

12 Ibid., p. 192-193.

13 Krotochwila (hasło), Stownik Języka Polskiego, Wydawnictwo Naukowe PWN, May 2017, http://sjp.pwn.pl/sjp/krotochwila;2475422.html (accessed: 29 May 2017).

14 C. Belsey, Agonistic scenes of provincial life, in: E. Gajowski, P. Rackin (eds.), The Merry Wives of Windsor. New Critical Essays, New York 2015, p. 27. 
no other play of Shakespeare's refers so insistently to the language that composes it: Falstaff calls the Welsh schoolmaster "one that makes fritters of English" (5.5.142); "here's a fellow/ frights English out of his wits", Page observes of poor Nim, who can barely complete a sentence without invoking "the humour of it" (2.1.124-25); Mistress Quickly expects from Dr Caius "an old abusing of God's patience and the King's English" (1.4.4-5); the Host of the Garter Inn comments that Parson Evans and Dr Caius would do better not to fight, but to keep their limbs whole and (continue to) hack the language instead (3.1.70-71). ${ }^{15}$

Shakespeare employs various comic devices, such as verbal tags, wordplay, or involuntary puns, which result from misunderstanding or mispronouncing words in English, as both men speak incorrectly, ungrammatically, with specific pronunciation patterns that are typical of the Welsh and French accents respectively, as perceived by the Elizabethan audiences. The editors of The Norton Shakespeare describe their speech in the following way: Evans "often pronounces $t$ for $d$, $p$ for $b$, and $f$ for $v$ and omits initial $w$... Caius's speech is marked similarly by the replacement of the $t h$ phoneme with a $d$ and the $w$ phoneme with a $v$ as well as by the addition of $-a$ at the end of some words" ${ }^{16}$ Moreover, Caius frequently incorporates French words and phrases into his utterances, as well as strives to translate them while speaking. His "nonnative pronunciation causes him to fall victim to bawdy puns". ${ }^{17}$

Dycalp strives to preserve the unique quality of Shakespeare's text and signal the comic specificity of Evans's and Caius's speech. Their language is incorrect in terms of spelling or grammar, but it is also difficult to understand, especially on the page. The strategy which Dycalp employed in order to render verbal humour relies on the transcription of the idiosyncratic phonological features of both characters' speech. In the case of Evans, most consonants are devoiced, regardless of their position within the word: "tuzin" ('a dozen') becomes "tusin", "owad" ('an insect') - "ofat". Affricates are changed into fricatives: "bardzo" ('very') - "barso", or into other affricates: "człowiek" ('human') - "szlofiek". Caius's speech does not differ much from Evans's, but Dycalp preserves his original tendency to ad '-a' at the end of some words. In the Polish version, this feature creates an additional comic effect, as it makes Caius speak about himself as if he were a woman. ${ }^{18}$ There are also minor changes in his pronunciation: final consonants are voiced, unlike in the correct Polish pronunciation ("szlofieg" - "człowiek"; 'human'), the affricate rendered by the letter "cz" [ $\hat{\mathrm{t}}]$ is often changed into the affricate rendered by "sz" [J], there are numerous cases of devoicing, similar to

${ }^{15}$ G. Melchiori (ed.), William Shakespeare's The Merry Wives of Windsor. The Arden Shakespeare, London 2000, pp. 5-9, qtd. in: C. Belsey, op. cit., p. 27-28.

16 K.V. Santos, Hosting Language: Immigration and Translation in The Merry Wives of Windsor, in: R. Espinosa, D. Ruiter (eds.), Shakespeare and Immigration, New York 2016, pp. 64-65.

17 Ibid., p. 65.

18 The ending "-a" indicates the female gender of nouns and adjectives in Polish, e.g. "Wherefore shall I be content-a?" (W. Shakespeare, The Merry Wives of Windsor, H.J. Oliver (ed.), London-New York 1993, I.4.65) - "Ja będę spokojna. Szemu to ja będę spokojna. He?" (W. Shakespeare, Puste kobiety $z$ Windsoru [The Merry Wives of Windsor], John of Dycalp (transl.), Wilno 1842, p. 44). In Dycalp's 1842 translation, the lines are not numbered as is customary. Therefore, in the paper, the quotations from the translation are indicated by mentioning the page number. 
those already discussed in Evans's case. Moreover, Dycalp decides to include more French words in Caius's speech - in the Polish translation, he often says "bon" instead of the incorrect "vell" ("well'), "pardieu" instead of Shakespeare's "by gar".

It should be noted that, like Shakespeare, Dycalp employs not only weird pronunciation and lexical errors, but also grammatical errors to mark the strangeness of Caius's and Evans's speech. As Kathryn Santos observes, "Caius's primary difficulties are with first-person pronouns, verb tenses, and subject-verb agreement... . Evans similarly displays a tendency to use adjectives or adverbs as nouns and vice versa". ${ }^{19}$ All these linguistic characteristics can be found in Dycalp's translation. The fact that the unusual visual representation of the words on the page is even more eye-catching in Dycalp's version than in the original makes the linguistic aspect of the play even more dominant. The mistakes Dycalp puts in Evans's mouth seem more visible and more extreme than in the original text. However, Dycalp's text needs to be spoken aloud - only then is it possible to fully appreciate the humour of the translation, which is especially important since it is intended for the stage.

It is worth stressing that Dycalp is by no means an invisible translator. He supplies his translation with a considerable number of footnotes providing explanations, commentaries, and justifications of his choices, which he felt necessary for such a serious task as rendering Shakespeare into Polish. In one of the footnotes, he comments upon his (failed, as he claims) attempts to avoid similarities between Evans and Caius. Dycalp observes that Shakespeare himself did not distinctively mark differences in the two characters' speech. And more importantly, Dycalp decides to change Evans's nationality: in his translation, the parson is no longer Welsh, but German. According to Dycalp, the only difference in the Polish language spoken by the French and the Germans lies in the accent, and it is almost impossible to differentiate between them in the written text.$^{20}$ Interestingly, in the dramatis personae of the Polish translation, Sir Hugh Evans still features as a Welsh parson, even though in the text, he is persistently depicted as a German, "Zamorski Niemek" ('a little German from overseas') ${ }^{21}$, instead of a "mountain foreigner". ${ }^{22}$ Furthermore, in the Polish translation, Evans frequently uses German words, such as "rychtych" ("richtig" - 'true'), "nein" ("no'), "gut" ('well'), or "der Teufel" ("the devil'). To confuse the matters even more, he is explicitly referred to as a Welsh by the Host: "Cicho Gallijo i Wallijo! Gallu i Wallijczyku! lekarzu duszny i cielesny!"’23.

19 K.V. Santos, op. cit., p. 65.

20 W. Shakespeare, Puste kobiety z Windsoru [The Merry Wives of Windsor], John of Dycalp (transl.), Wilno 1842, fn. 7, pp. 41-42.

21 Ibid., p. 19.

22 W. Shakespeare, The Merry Wives of Windsor, H.J. Oliver (ed.), London-New York: Routledge, I.1.144.

23 W. Shakespeare, Puste kobiety z Windsoru, op. cit., p. 101. "Peace, I say, Gallia and Gaul, French and Welsh, soul-curer and body-curer!"; W. Shakespeare, The Merry Wives of Windsor, op. cit., III.1.89-90. 
To some extent, this radical (although inconsistent) change of Evans's nationality in the Polish translation might be justified by Dycalp's pursuit of a dynamic, or functional equivalence. This domesticating strategy distorts the geographic logic of the original play, but makes its linguistic confusion far more understandable for the target audience, who hosted many Polish-speaking Germans. Interestingly, Dycalp does not try to come up with another solution, such as finding an equivalent in terms of another dialect or another linguistic form, and thus preserves the original functional difference between the English and the Welsh accent in English.

Moreover, it should be noted that Dycalp never gives in when it comes to translating more complex, especially comic, passages, which are often omitted by subsequent translators. This is the case of the passage quoted below, which is entirely omitted by Józef Paszkowski, one of the three most eminent $19^{\text {th }}$-century translators of Shakespeare into Polish ${ }^{24}$ :

SLENDER All his successors gone before him hath done't, and all his ancestors, that come after him may: they may give the dozen white luces in their coat.

EVANS The dozen white louses do become an old coat well; it agrees well, passant; it is a familiar beast to man, and signifies love.

SHALLOW The luce is the fresh fish; the salt fish is an old coat.

SLENDER I may quarter, coz.

SHALLOW You may, by marrying.

EVANS It is marring indeed, if he quarter it.

SHALLOW Not a whit.

EVANS Yes, py'r lady; if he has a quarter of your coat, there is but three skirts for yourself, in my simple conjectures: but that is all one. If Sir John Falstaff have committed disparagements unto you, I am of the church, and will be glad to do my benevolence, to make atonements and compromises between you. ${ }^{25}$

In the original, there are puns on the words "coat", which might signify either a coat of arms or a piece of clothing, and "luce" ("pike"), which Evans mispronounces as "louses" ("lice"). In the case of "coat", Dycalp opts only for a piece of clothing and uses the word "czamara" (mispronounced as "szamara"), a borrowing from Hungarian, which might sound foreign to the Polish ear. ${ }^{26}$ However, he manages to retain the second wordplay, by translating "luce" as "ryśs" ("a lynx").

24 Józef Paszkowski's translation of The Merry Wives of Windsor was published in 1877 in the third volume of Dzieła dramatyczne Williama Shakespeare [William Shakespeare's Dramatic Works], edited by Józef Ignacy Kraszewski (W. Shakespeare, Figle kobiet [The Merry Wives of Windsor], J. Paszkowski (transl.), in: J.I. Kraszewski (ed.), Dzieła dramatyczne Williama Shakespeare (Szekspira). Wydanie ilustrowane ozdobione 545 drzeworytami rysunku H.C. Selousa, vol. 3, Warszawa 1877, pp. 97-154). Interestingly, Paszkowski also decided to alter the title of the play - his translation is entitled Figle kobiet [Women's Tricks]. He also attempts to render the verbal humour in the play by means of imitating foreigners' pronunciation.

25 W. Shakespeare, The Merry Wives of Windsor, op. cit., I.1.14-31.

26 Czamara (hasło), Stownik Języka Polskiego, Wydawnictwo Naukowe PWN, May 2017, http:// sjp.pwn.pl/slowniki/czamara.html (accessed: 29 May 2017). 
He juxtaposes it with the word "ryśka", which means an insect, a fly, thus retaining the wordplay ${ }^{27}$ :

SLENDER W ten sposób podpisywali się przed nim wszyscy jego następcy, i w ten sposób będą mogli podpisywać się po nim wszyscy jego przodkowie: dziś jeszcze mogą oni ukazać na tuzin rysiów w swojej dziedzicznej czamarze.

EVANS Che! che! che! Tusin rysiof f szamasze! Ryś, fona szepla szamara lubi. Che! che! che! ta ofat barso szlofiek lubi.

SHALLOW Jest tu mowa o rysiu puszczowym, i rzecz idzie o starożytności herbu.

SLENDER Nie prawdaż mój Stryju, że ja go mogę rozdzielić na dwa pola?

SHALLOW Zapewne że możesz synowcze przez węzeł małżeński.

EVANS Sa posfoleniem! fęslem my kompinuje, ląszy, a nie zieli. Ale to nie fielka artykul! Szeby pofrosić do nasza rzesz, ja pofiata sze kiedy Sir Dżon Falstaff dopuścili się na mego Doproziej jaka niekrzeszność, ja jako duchofna person musi nastroić ta sprafa na polupowny manier. ${ }^{28}$

The Shakespearean pun on the words "marrying" and "marring" is replaced in Dycalp's version by the image of the marital knot ("węzeł małżeński"), which, according to Evans, does not serve to divide coats of arms, but to unite people. It seems that it might serve as an instance of the appropriation for the target audience, pruning the text of indecencies. Dycalp resorts to this strategy quite frequently. For example, in the Polish text, Falstaff never kisses Mistress Ford, but only embraces her. Appropriation also applies to the passages featuring biblical quotations (specifically the Psalms). In one of the footnotes, Dycalp openly admits that he replaces those passages with quotes from Horace, which he obviously finds safer from his somewhat purist moral point of view. ${ }^{29}$ In the case of Caius, he softens some of the bawdier jokes. For example, when Caius challenges Evans to a duel, he sends him a letter and threatens to injure him seriously: "I will cut all his two stones; by gar, he shall not have a stone to throw at his dog". ${ }^{30}$ Needless to say, by "two stones" Caius clearly implies Evans's testicles. Dycalp replaces this bawdy threat with the apparently less controversial "ears" ("uszy"), and then concludes rather incoherently that Evans "will not have a bone to throw at his dog". ${ }^{31}$

Undoubtedly, the real treasure chest of humour of The Merry Wives of Windsor is to be found in the scene where Evans teaches young William Latin, while Mistress Quickly, listening to the lesson, confuses what she hears with vulgar and obscene words. ${ }^{32}$ Dycalp yet again decides to tone down the sexual innuendos. He replaces the wordplay on "pulcher" and "polecats" with "senex" and "senes" (respectively: "old" and "a herb"), but tries to retain the pun on the word "caret" by

27 Ryśka (hasło), Edycja elektroniczna słownika wileńskiego, 1861, https://eswil.ijp.pan.pl/index. php (accessed: 29 May 2017).

28 W. Shakespeare, Puste kobiety z Windsoru, op. cit., pp. 8-9.

29 Ibid., fn. 10, p. 58.

30 W. Shakespeare, The Merry Wives of Windsor, op. cit., I.4.102-108.

31 Idem, Puste kobiety z Windsoru, op. cit., p. 46.

32 Idem, The Merry Wives of Windsor, op. cit., IV.1.18-71; T. Hoenselaars, Foreign languages and foreign language learning, in: B.R. Smith (ed.), The Cambridge Guide to the Worlds of Shakespeare. Volume 2. The World's Shakespeare, 1660-Present, New York 2016, p. 202. 
using the Polish word "kareta" ("a carriage") and, thus, loses the sexual undertone of the joke. Dycalp also refrains from using vulgar words in the "horum, harum, horum" passage - he decides to retain the meaning grasped by Mistress Quickly, ${ }^{33}$ but he uses the similarity between the Latin word "barbarus" and the female name "Barbara" instead. Evans asks William to decline the adjective while Mistress Quickly is appalled: "Wstydź się, wstydź się Pan, po co ma wiedzieć dziecko o przypadkach tej niegodziwej Barbary!" ("Shame on you, sir, the child should not know anything about that wicked Barbara's affairs!"). ${ }^{34}$

Kathryn Vomero Santos remarks that in the characters Dr Caius and Sir Hugh Evans, Shakespeare envisions the "suspension between two cultures", 35 a motif that was recognized as holding various dramatic and comic merits by many English playwrights of the time. Similarly, Dycalp, who spent his life in the region of the Polish Borderlands, transfers Shakespeare's comedy to the familiar multicultural environment, a melting pot of sorts, where people of different cultures and languages inhabited the same space.

This specific aspect of Dycalp's translation is apparent in the Polish title of the play: Puste kobiety z Windsoru. The canonical translation of Shakespeare's comedy into Polish is now Wesote kumoszki z Windsoru, which instead of emphasising the marital status of Mistress Ford and Mistress Page, underlines the bonds of friendship that make them plot together against Falstaff. The colloquial meaning of the word "kumoszki" (sing. "kumoszka") is female friends, gossips; however, the first meaning provided in the Dictionary of the Polish Language (Słownik Języka Polskiego) implies "nosy, talkative women". ${ }^{36}$ Dycalp opts for emphasising the characters' gender by translating "wives" as "kobiety" ("women'). Moreover, he forgoes the adjective "merry" ("wesołe") and replaces it with a word "puste", which, according to Samuel Linde's Dictionary, means "empty" (as in: empty laughter), "coy", and "playful". ${ }^{37}$ The Dictionary of the Polish Language edited by Władysław Niedźwiedzki goes even further by offering synonyms such as "thoughtless, reckless, pointless, futile, or scatterbrained". 38 Also the modern Dictionary of the Polish Language defines "pusty" as "empty, reckless, idle, poor", or even "worthless". ${ }^{39}$ Thus, the phrase "puste kobiety" not only differs from the "merry wives" or Polish "wesołe kumoszki" but sounds somewhat scornful from the perspective of Dycalp's times and outright negative from the modern point of view.

33 "Vengeance of Jenny's case! fie on her! never name her, child, if she be a whore", W. Shakespeare, The Merry Wives of Windsor, op. cit., IV.1.54-55.

34 Idem, Puste kobiety z Windosru, op. cit., p. 149.

35 K.V. Santos, op. cit., p. 64.

36 Kumoszka (hasło), Słownik Języka Polskiego, Wydawnictwo Naukowe PWN, May 2017, http://sjp.pwn.pl/sjp/kumoszka;2476510.html (accessed: 29 May 2017).

37 Pusty (hasło), Stownik języka polskiego Samuela Lindego, T. 2, cz. 2: P. 1811, http://kpbc.umk. pl/publication/8173 (accessed: 29 May 2017).

38 Pusty (hasło), Stownikjęzyka polskiego ułożony przez Władysława Niedźwieckiego, T. 5, 1909, http://ebuw.uw.edu.pl/publication/254 (accessed: 29 May 2017).

39 Pusty (hasło), Stownik Języka Polskiego, Wydawnictwo Naukowe PWN, May 2017, https:// sjp.pwn.pl/szukaj/pusty.html (accessed: 29 May 2017). 
Thus, Dycalp's translation might appear to be slightly prejudiced towards women, if not tainted with misogyny: the choice of the adjective in the title might suggest that the translator does not approve of their actions. In comparison, other $19^{\text {th }}$-century translators, such as Józef Paszkowski or Leon Ulrich, chose to translate the title of the comedy as Figle kobiet ['Women's Jokes' or 'Women's Tricks' $]^{40}$, therefore emphasising the comic quality of heroines' plots, while Felicjan Faleński chose to underline their social status in his rendering of the title as Wesole mieszczki z Windsoru ['The Merry Townswomen of Windsor'] ${ }^{41}$. Dycalp's decision might imply a patronising attitude towards women. This sense of inequality is also visible in the translator's attitude towards Mistress Quickly (translated as "Pani Żwawska"), which is expressed in one of the footnotes: "Mistress Quickly, like Slender, perceives Latin words as insults; however, as many women tend to do, she is not able to fight the temptation to use the words she does not understand" ${ }^{42}$ It seems that by providing such a commentary, the translator refers to some universally acknowledged truth that he and his readers share.

Another way of bringing the translation closer to its target audience is to incorporate elements that are specific to the target culture. For instance, when translating Ford's lines: "Love like a shadow flies when substance love pursues; Pursuing that that flies, and flying what pursues" ${ }^{43}$ Dycalp uses the translation of (presumably) Julian Ursyn Niemcewicz, a famous Polish poet and playwright: "Miłość jest jak cień człowieka,/Szkoda kto dla niej wiek trwoni,/Kiedy ją gonisz, ucieka,/ Kiedy uciekasz, to goni" ${ }^{44}$ In a footnote, he informs the reader that this piece of poetry was inserted in the text exactly as it had been carved on the tree in the property of the Niemcewicz family, near the city of Brześć Litewski (now Belarus). ${ }^{45}$ Not only does he quote the text by an eminent Polish writer, which is a clearly domesticating decision, but he also provides the very specific location at which the quoted text could be appreciated. Thus, Dycalp domesticates the text by first employing elements of the target culture, and secondly, clearly acknowledging it. When Dycalp refers to famous Polish poets, such as Julian Ursyn Niemcewicz or Juliusz Słowacki ${ }^{46}$, his imagery tends to drift away from Shakespeare's text towards more familiar motifs.

Interestingly, this strategy of familiarising Shakespeare's play is not consistent throughout the whole translation. Although it seems that Dycalp intends to keep

40 W. Shakespeare, Figle kobiet [The Merry Wives of Windsor], transl. by L. Ulrich, Dzieta dramatyczne Williama Shakespeare (Szekspira): w dwunastu tomach, T. 9, Kraków-Warszawa 1895, pp. 11-95.

41 Idem, Wesole mieszczki z Windsoru [The Merry Wives of Windsor], transl. by F. Faleński, “Tygodnik Mód i Powieści” 1875, no. 16-26.

42 Idem, Puste kobiety z Windsoru, op. cit., fn. 9, p. 44.

43 Idem, The Merry Wives of Windsor, op. cit., II.2.201-202.

44 J.U. Niemcewicz, Miłość jest jak cień czlowieka..., in: W. Shakespeare, Puste kobiety z Windsoru [The Merry Wives of Windsor], John of Dycalp (transl.), Wilno 1842, p. 81.

45 W. Shakespeare, Puste kobiety z Windsoru, op. cit., fn. 12, p. 81.

46 J. Słowacki, Do pastereczki siedzacej na druidów kamieniach w Pornic nad oceanem, "Biblioteka Literatury Polskiej w Internecie", http://literat.ug.edu.pl/ literat/jswiersz/052.htm (accessed: 29 May 2017). 
close to the reality of the Borderlands, at one point, he includes also an element that originates from a different region of Poland. In the dialogue at the beginning of the fifth act: "I come to her in white, and cry 'mum'; she cries 'budget'; and by that we know one another", ${ }^{47}$ instead of simply translating the passwords, he proposes calls which were, at his time, used by the peasants from Masovia (the region in the modern central Poland): "Podejdę do białej i powiem jej: Szmi!, ona mi odpowie: Szma, i po tem się poznamy" ("I come to her in white, and tell her Szmi!, she will answer me Szma, and by that we know each other"). ${ }^{48}$

It should also be stressed that Dycalp attempts to domesticate the text not only by relocating it into a reality that is better known to the Polish reader, or even specifically to the reader from the region of Kresy. He also carefully explains those aspects of the text that might seem unfamiliar to the Polish reader, or which he chooses to preserve in the target language. For example, he explains the names of institutions, albeit not consistently throughout the translation: he translates the name of the Star Chamber and puts the original version in a footnote, but later he does not translate "Counter-gate", opting to provide the explanation in a footnote instead. ${ }^{49}$ Another example of this strategy is the inclusion of explanations of customs and traditions that need to be elaborated upon: in the second scene of the third act, Dycalp explains the custom of young peasants to keep buds of bachelor's buttons in their pockets, as their blooming or withering told them how would their love affairs go. ${ }^{50}$

As for the English customs and traditions described in Shakespeare's text, it is especially interesting to analyze the most culture-specific passage of the mascarade and cross-dressing, and the reference to Herne the Hunter, the ghost of the Windsor Forest. ${ }^{51}$ Here Dycalp preserves the specifically English folk or mythological elements of the play. However, he introduces some changes: for instance, he replaces the oak with the sycamore tree ("jawor"), which held a symbolic meaning in the Slavic tradition. It was often treated as a tree at which lovers used to meet - the belief is to be found in a famous pastoral, "Laura and Filon" ("Laura i Filon"), by Franciszek Karpiński, a poet born in the region of Borderlands. ${ }^{52}$ Nevertheless, it should be noted that the oak was also considered to be a sacred tree in the Slavic mythology. Dycalp's decision to replace it with the sycamore might, on the one hand, refer to the "romantic" plot involving Falstaff, Mistress Ford, and Mistress Page, or, on the other, it might result from some stylistic modifications of the text, necessary to preserve the prosodic features of the passage (i.e. its rhymes and rhythm). ${ }^{53}$

47 W. Shakespeare, The Merry Wives of Windsor, op. cit., V.2.5-7.

48 Idem, Puste kobiety z Windsoru, op. cit., pp. 187-188.

49 Ibid., fn. 1, p. 7; fn. 17, p. 116.

50 Ibid., fn. 14, pp. 108-109.

51 Idem, The Merry Wives of Windsor, op. cit., IV.4.28-38.

52 F. Karpiński, Laura i Filon, "Biblioteka Literatury Polskiej w Internecie", http://iterat.ug.edu. pl/krpnski/002.htm (accessed: 29 May 2017).

53 W. Shakespeare, Puste kobiety z Windsoru, op. cit., pp. 169-170. 
Another aspect worth examining is the appearance of the fantastic creatures and the way the words denoting them are rendered into Polish. In Shakespeare's text, Mrs Page enumerates "urchins, ouphes, and fairies", while in Dycalp's translation, there are "sylfy, gnomy i rusałki" ('sylphs, gnomes and water nymphs'). Urchins and ouphes seem too exotic and untranslatable for the Polish context, but still the translator opts for less culture-specific sylphs and gnomes. However, his choice to translate "fairies" as "rusałki" puts the text specifically in the context of Slavic culture: rusałki (singular: "rusałka"), or water nymphs, were demonic creatures that tempted young men. Probably due to their negative associations, Dycalp later replaces Shakespeare's "fairies" not only with "rusałki", but also with words such as "duchy" ('ghosts'), "elfy" ('elves'), and "upiory" ('demons').

Dycalp remains close to the original text in terms of expressing thoughts and emotions, but he does not hesitate to elaborate or even alter the text when he sees it necessary. Thus, the majority of Dycalp's translations were seen by their critics as "detailed summaries of foreign works of literature" rather than proper translations. ${ }^{54}$ The scarce reviews acknowledge Dycalp's undeniable talent, but castigate him for what was seen as unfaithfulness, carelessness or neglect. ${ }^{55}$

However, the most serious charges refer to Dycalp's choice of register, his frequent omissions and substitutions. ${ }^{56}$ Another target of the critique is his strategy of appropriation and the stylistic features of his translation. Dycalp's mocking and deliberate overuse of the genitive case, strange syntactic constructions, and borrowings from foreign languages won hardly any approval. ${ }^{57}$

In contrast, the judgement expressed by Dycalp's befriended contemporaries seems much more favourable: Ignacy Hołowiński called Puste kobiety $z$ Windsoru "a model translation": faithful, comic, natural, and accurate. ${ }^{58}$ However, even from today's perspective, it is possible to notice and appreciate the positive and innovative aspects of Dycalp's translation, which, on the one hand, may be treated as a linguistic experiment, while, on the other, thanks to the strategy of domestication, they may be seen as an effort to endow Shakespeare's comedy with a new and unexpected dimension. Dycalp aims his translation at a very specific audience and thus he augments the multilingual dimension of Shakespeare's comedy, enriching it with "a local habitation and name". Consequently, for Dycalp an acting stage seems to denote a broadly understood cultural space.

It is often claimed that every translation has its use-by date. Translations that are rejected by their own time rarely have a chance to enter the canon afterwards, as they have already been replaced with new texts. However, they are a valuable source of information about the past. Their aesthetic specificity as well as their cultural and linguistic wealth bear witness to the reality of the contemporary "hosting culture". Dycalp's translations of Shakespeare's plays appear inherently

54 W. Charkiewicz, op. cit., p. 158.

55 Ibid.; W. Tarnawski, op. cit., p. 59.

56 W. Tarnawski, op. cit., p. 61.

57 Ibid., p. 68.

58 Ż. Kostrowiec (I. Hołowiński), Krytyka: John of Dycalp, "Pamiętnik Elfa», "Tygodnik Petersburski" 1843 , no. 55, p. 325. 
peripheral and, at the same time, very rare and immensely genuine in the way they try to merge the realities of the text and those of the audience. From today's perspective, that forgotten translation of The Merry Wives of Windsor preserves the world that no longer exists and appears very distant, enigmatic, and altogether lost to the modern readership.

\section{References}

Belsey C., Agonistic scenes of provincial life, in: E. Gajowski, P. Rackin (eds.), The Merry Wives of Windsor. New Critical Essays, New York 2015, pp. 27-37.

Blank P., Dialects in the plays of Shakespeare, in: B.R. Smith (ed.), The Cambridge Guide to the Worlds of Shakespeare. Volume 2. The World's Shakespeare, 1660Present, New York 2016, pp. 219-223.

Cetera A., Smak morwy. U źródet recepcji przekładów Szekspira w Polsce, Warszawa 2009.

Charkiewicz W., Placyd Jankowski (John of Dycalp). Życie i twórczość, Wilno 1928.

Czamara (hasło), Słownik Języka Polskiego, Wydawnictwo Naukowe PWN, May 2017, http://sjp.pwn.pl/slowniki/czamara.html (accessed 29 May 2017).

Delabastita D., "If I know the letters and the language»: translation as a dramatic device in Shakespeare's plays, in: T. Hoenselaars (ed.), Shakespeare and the Language of Translation, London 2012, pp. 31-52.

Delabastita D., Hoenselaars T., "If but as well I other accents borrow, that can my speech diffuse». Multilingual perspectives on English Renaissance drama, in: D. Delabastita, T. Hoenselaars (eds.), Multilingualism in the Drama of Shakespeare and His Contemporaries, Amsterdam-Philadelphia 2015, pp. 1-15.

Hoenselaars T., Foreign languages and foreign language learning, in: B.R. Smith (ed.), The Cambridge Guide to the Worlds of Shakespeare. Volume 2. The World's Shakespeare, 1660-Present, New York 2016, pp. 198-205.

Karpiński F., Laura i Filon, "Biblioteka Literatury Polskiej w Internecie”, http://literat.ug.edu.pl/krpnski/002.htm (accessed: 29 May 2017).

Komorowski J., Polskie szekspiriana. 2. Shakespeare księdza Kefalińskiego, "Pamiętnik Teatralny" 1991, no. 1, pp. 11-17.

Komorowski J., Shakespeare and the Birth of Polish Romanticism: Vilna 1786-1846, "Theatre Research International" 1996, no. 2, pp. 141-146.

Komorowski J., Shakespeare w Wilnie 1786-1864, "Pamiętnik Teatralny" 1986, no. 2-3, pp. 181-200.

Kostrowiec Ż. (I. Hołowiński), Krytyka: John of Dycalp, «Pamiętnik Elfa», "Tygodnik Petersburski" 1843, no. 55, p. 325.

Krotochwila (hasło), Słownik Języka Polskiego, Wydawnictwo Naukowe PWN, May 2017, http://sjp.pwn.pl/sjp/krotochwila;2475422.html (accessed: 29 May 2017).

Kumoszka (hasło), Słownik Języka Polskiego, Wydawnictwo Naukowe PWN, May 2017, http://sjp.pwn.pl/sjp/kumoszka;2476510.html (accessed: 29 May 2017).

Miłosz Cz., Native Realm: A Search for Self-definition, C.S. Leach (transl.), Berkeley 1981. 
Niemcewicz J.U., Miłość jest jak cień człowieka..., in: W. Shakespeare, Puste kobiety $z$ Windsoru [The Merry Wives of Windsor], John of Dycalp (transl.), Wilno 1842, p. 81.

Pusty (hasło), Słownik języka polskiego Samuela Lindego, T. 2, cz. 2: P. 1811, http:// kpbc.umk.pl/publication/8173 (accessed: 29 May 2017).

Pusty (hasło), Słownik języka polskiego ułożony przez Władysława Niedźwieckiego, T. 5, 1909, http://ebuw.uw.edu.pl/publication/254 (accessed: 29 May 2017).

Ryśka (hasło), Edycja elektroniczna słownika wileńskiego, 1861, https://eswil.ijp.pan. pl/index.php (accessed: 29 May 2017).

Santos K.V., Hosting Language: Immigration and Translation in The Merry Wives of Windsor, in: R. Espinosa, D. Ruiter (eds.), Shakespeare and Immigration, New York 2016, pp. 59-72.

Shakespeare W., Figle kobiet [The Merry Wives of Windsor], J. Paszkowski (transl.), in: J.I. Kraszewski (ed.), Dzieła dramatyczne Williama Shakespeare (Szekspira). Wydanie ilustrowane ozdobione 545 drzeworytami rysunku H.C. Selousa, vol. 3, Warszawa 1877, pp. 97-154.

Shakespeare W., Figle kobiet [The Merry Wives of Windsor], L. Ulrich (transl.), in: Dzieła dramatyczne Williama Shakespeare (Szekspira): w dwunastu tomach, t. 9, Kraków 1895, pp. 11-95.

Shakespeare W., The Merry Wives of Windsor, H.J. Oliver (ed.), London-New York 1993.

Shakespeare W., Puste kobiety z Windsoru [The Merry Wives of Windsor], John of Dycalp (transl.), Wilno 1842.

Shakespeare W., Wesote mieszczki z Windsoru [The Merry Wives of Windsor], F. Faleński (transl.), “Tygodnik Mód i Powieści” 1875, no. 16-26.

Słowacki J., Do pastereczki siedzacej na druidów kamieniach $w$ Pornic nad oceanem, "Biblioteka Literatury Polskiej w Internecie", http://literat.ug.edu.pl/ literat/ jswiersz/052.htm (accessed: 29 May 2017).

Tarnawski W., O polskich przekładach dramatów Szekspira, Kraków 1914.

Żurowski A., Szekspiriady polskie, Warszawa 1976. 